\title{
Occlusion of the Venom Duct of Crotalidae by Electrocoagulation: an Innovation in Operative Technique. ${ }^{1}$
}

\author{
Duval B. Jaros \\ Riverside, Illinois.
}

(Text-figure 1).

An article by Tait $^{2}$ on the surgical removal of the venom glands of rattlesnakes prompted Mr. Emil Rokosky of the Chicago Zoological Park to suggest the use of electrocoagulation on the venom gland. It was thought, however, that occlusion of the duct would be a less drastic procedure than removal of the gland. In addition, conservation of the gland would permit interesting experiments and histologic studies. The immediate problem presented was the development of the technical details of a rapid operation which would occlude the duct, preserve the gland and result in minimum injury to the snake. In the procedure here outlined, electrocoagulation is employed.

Electrocoagulation produces destruction of tissue by heat, and corresponds to the solidifying of the white of an egg during boiling. The heat of electrocoagulation, however, is not conducted but is induced within the tissue itself, which insures coagulation without even surface carbonization. The coagulum is sterile and simulates a scab, nature's own wound covering. Sterility, firmness and pliability of the coagulum permit healing without scarring.

Essentials of an electrocoagulating device are two electrodes and a high frequency current. The electrodes may be in the form of a single duoterminal instrument, a body-plate and a point, or as in the present experiment, two separate uniterminal instruments with one serving also as the probe for securing the duct.

The high frequency current alternates at about one million cycles per second. Suitable currents can be obtained from simple spark-gap or thermionic tube apparatuses sold by all physiotherapy equipment dealers. The coagulating current of 800 kilocycles, 150 milliamperes and 2000 volts, seals the severed ends of the duct, and is therefore preferable to the cutting current.

In the operation, several innovations employed made general anaesthesia unnecessary and facilitated single-handed performance with relative safety to the operator and the snake. The first device, an operating board (Textfig. 1) was designed to hold the snake firmly and prevent it from thrashing. The board was fitted with a neck pad, strap and a thin rubber restraining flap for the body. When in use, this flap was drawn over the snake and attached along the opposite edge of the board by a zipper running its entire

\footnotetext{
1 Presented at a meeting of the Amateur Herpetologist Group of the Chicago Academy of Sciences, June 15, 1939, and at the annual meeting of the American Society of Ichthyologists and Herpetologists, Chicago, September 14, 1939.

2 Copeia, 1938:1.
} 
length. Pressed down by the restraining sheet which yields to its struggles, the snake cannot crawl. This operative convenience can be augmented by having the surface of the board on which the snake rests very smooth or covered with yielding rubber similar to the overlying restraining sheet.

A second aid was the surgical skin clip or Michel clip. These clips, small strips of metal clawed at each end and preferably bent into a $\mathrm{V}$ shape, when pressed point to point, firmly grasp any interposed tissue. Applied to the snake's lips, they hold the snake's mouth shut and make handling relatively safe without the use of general anaesthesia.

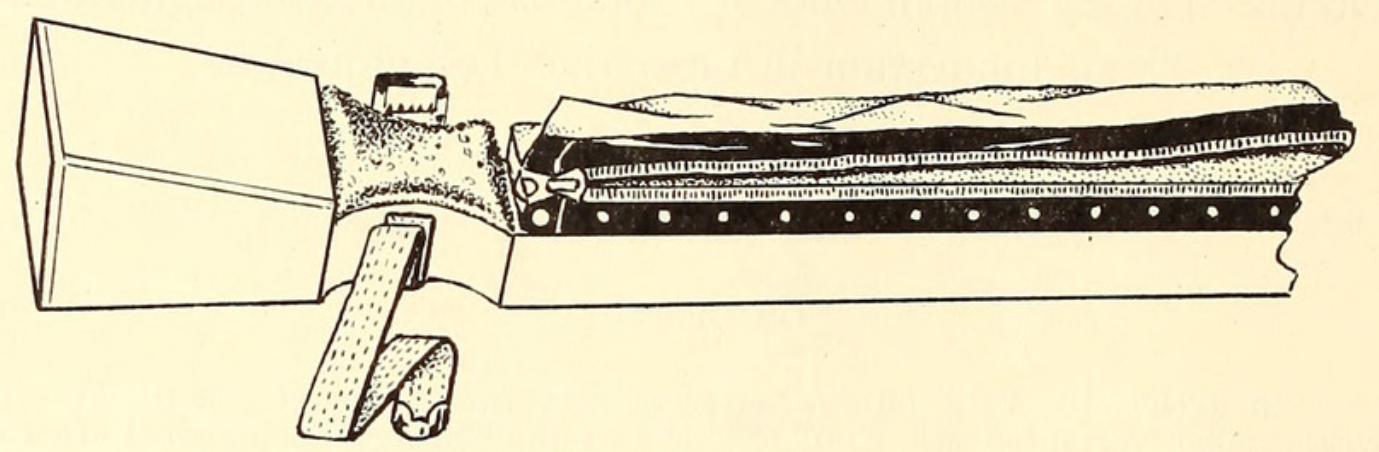

Text-figure 1 .

Operating board designed to hold a snake firmly while the venom duct is occluded.

Another innovation was an improvised scalpel which proved, for my purpose, to be superior to any other obtainable. These scalpels were made from slivers of the cutting edges of Gillette "Thin Blades," broken off with pliers and clamped in ordinary artery forceps. With the forceps serving as handles, these tiny bayonettes afforded a generous supply of extremely sharp, delicate and inexpensive knives.

\section{THE OPERATION.}

The snake, grasped behind the head, was fastened to the operating board, and Michel clips were clamped on the lips; one on each side below the pit. Care was taken not to include the mandible.

At this time, if desired, a local anaesthetic may be injected at the site of the incision. A $2 \%$ procain borate solution was used. Almost immediately after the injection a quarter-inch incision was made just below the eye and on a level with the pit. Through this small incision the duct was secured and drawn out with a blunt curved probe. When clear of the surrounding tissue, it was coagulated sufficiently to sever it. The severed ends were dropped back into place and the wound was touched with tincture of merthiolate. The wound was so small, and there was so little trauma, that sutures were unnecessary and healing was remarkably rapid. In many cases it was difficult to locate the site of incision after one week.

As the snake is not deprived of glands or fangs, the outward appearance of the head remains unaltered. In the specimens under observation no change in disposition was noticed; feeding remained regular in those which ate regularly before treatment. Each specimen was tested weekly by allowing it to bite a rabbit. In every case the result was negative. A cottonmouth moccasin, (Agkistrodon piscivorus) in good health forty-five weeks after treatment and eating well, was nevertheless unable to inflict other than mechanical injuries when biting. Deaths resulted from causes other than the operation-from mouth rot and intestinal disorder. 
The obstructed glands taken from snakes three, seven and eight weeks, and ten months, after treatment were sectioned for microscopic examination. The sections were studied by Dr. George J. Rukstinat, Associate Professor of Pathology at Rush Medical College. He found large acinar spaces filled with secretion, and lined by cells which evidently became cuboidal as a result of the retained venom; but even the compressed cells showed little signs of atrophy. In portions of the sections normal columnar cells survived. Nuclei and cytoplasm were demarcated clearly. Confluence of acini in some regions seemed apparent from the remnants of acinar walls which projected into the lumens of the cyst-like spaces. Many cells contained clear or slightly stippled vacuoles, the character of which is being investigated.

The histological evidences of cell viability were corroborated by the sub-cutaneous injection into mice of secretion from the glands of one snake which was killed ten months after occlusion of the duct. Minute quantities $(0.02 \mathrm{cc}$.$) of this secretion proved fatal to mice in four hours, and induced$ the usual changes of a general haemolysis and of local necrosis.

The potentialities for study of the venom gland through this method are numerous. Perhaps some internal absorption of secretion occurs; or perhaps some specialized cells elaborate components of venom as do specialized cells in organs such as the pancreas.

\section{SUMMARY.}

A method of rendering venomous serpents harmless is presented. Electrocoagulation is used to prevent, by the destruction of a portion of the duct, the escape of venom from the gland and its passage to the fang. The operator can manage, unassisted and with safety, the entire procedure. The snake is but slightly injured and is not disfigured. The desired results are apparently permanent. The habits of none of the thirty-six snakes treated seemed in any way effected by the operation, even after forty-five weeks. The operation was successfully performed on crotalids ranging in size from eight inches to four feet.

In the performance of the operation three innovations were introduced: a practical device for holding the snake, a cheap and efficient operating knife, and the use of Michel surgical clips to eliminate all danger of being bitten.

I wish to express my grateful acknowledgement to Dr. George J. Rukstinat, to Mr. Walter L. Necker of the Chicago Academy of Sciences, and to Mr. Emil J. Rokosky, for advice and encouragement; and to my father, Dr. Joseph F. Jaros, for his help with the technical aspects of the work. 


\section{$2 \mathrm{BHL}$ Biodiversity Heritage Library}

Jaros, Duval B. 1940. "Occlusion of the venom duct of Crotalidae by electrocoagulation: an innovation in operative technique." Zoologica : scientific contributions of the New York Zoological Society 25(4), 49-51. https://doi.org/10.5962/p.203602.

View This Item Online: https://www.biodiversitylibrary.org/item/207511

DOI: https://doi.org/10.5962/p.203602

Permalink: https://www.biodiversitylibrary.org/partpdf/203602

\section{Holding Institution}

Smithsonian Libraries

\section{Sponsored by}

Biodiversity Heritage Library

\section{Copyright \& Reuse}

Copyright Status: In Copyright. Digitized with the permission of the rights holder

Rights Holder: Wildlife Conservation Society

License: http://creativecommons.org/licenses/by-nc/3.0/

Rights: https://www.biodiversitylibrary.org/permissions/

This document was created from content at the Biodiversity Heritage Library, the world's largest open access digital library for biodiversity literature and archives. Visit BHL at https://www.biodiversitylibrary.org. 